\title{
THE NEOGENE-QUATERNARY EVOLUTION OF THE KARST LANDSCAPE OF THE VESZPRÉM PLATEAU BASED ON THE STUDY OF MEGGYESPUSZTA PALEODOLINE, HUNGARY
}

\author{
NEOGENSKO-KVARTARNI RAZVOJ KRAŠKEGA POVRŠJA \\ PLANOTE VESZPRÉM NA OSNOVI RAZISKAV PALEOVRTAČE \\ MEGGYESPUSZTA, MADŽARSKA
}

Attila János TRÁJER ${ }^{1,2}$, Tamás HAMMER ${ }^{1}$, Lilla MILINÁRIK ${ }^{3}$, Ákos BEDE-FAZEKAS ${ }^{4,5}$ \& Judit PADISÁK ${ }^{1,2}$

\begin{abstract}
UDC 551.435.8(439)

Attila János Trájer, Tamás Hammer, Lilla Mlinárik, Ákos Bede-Fazekas \& Judit Padisák: The neogene-quaternary evolution of the karst landscape of the Veszprém plateau based on the study of Meggyespuszta paleodoline, Hungary

The development and the geological activity of the Meggyespuszta paleodoline in Hungary were reconsidered in the light of new findings and review of complex stratigraphic and morphological results. Methods included geomorphological modeling, field geological re-surveys of the data from the existing boreholes and study of the sediments of a newly drilled borehole. Three main phases of the topography evolution were determined: (1) a presumably Early-Middle Neogene primer karstification period, (2) a Late Neogene-Early Quaternary partial charging with typical terrestrial red clay and dolomite silt sediments, (3) and the covering of the paleodoline with loess and loess-based soil cover during the Quaternary. While the south erosion valley was formed likely during Pliocene-Early Pleistocene period, the young, Holocene gullies were found only in the North and East part of the paleodoline. The rearrangement of rainwater course directions could be the consequence of the thinning of the loess sediment from North to South due to the wetter climatic conditions of the Holocene. Based on the oxidized filling sediments, the lack of peat or other lacustrine deposits and the low water content of the sediments above the bedrock, it was concluded that Meggyespuszta paleodoline is one of the largest still active sinkhole in the Transdanubian Range.

Keywords: paleodoline, paleokarst, Transdanubian Range, Transdanubian karst type.
\end{abstract}

\begin{abstract}
Izvleček
UDK 551.435.8(439)

Attila János Trájer, Tamás Hammer, Lilla Mlinárik, Ákos Bede-Fazekas \& Judit Padisák:: Neogensko-kvartalni razvoj kraškega površja planote Veszprém na osnovi raziskav paleovrtače Meggyespuszta, Madžarska

$\mathrm{Na}$ osnovi novih stratigrafskih in morfoloških raziskav orišemo geološki razvoj in funkcijo paleovrtače Meggyespuszta. Metode vključujejo geomorfološko modeliranje ter geološko kartiranje in obdelavo podatkov vrtin. Razvoj topografije vrtače delimo $\mathrm{v}$ tri faze: 1) začetno obdobje zakrasevanja $\mathrm{v}$ zgodnjem in srednjem neogenu, 2) pozno neogensko in zgodnje kvartarno polnjenje z rdečo glino in dolomitnim meljem, 3) pokrivanje paleovrtače $s$ puhlico in $\mathrm{z}$ njo povezano prstjo $\mathrm{v}$ kvartarju. Erozijske doline so se oblikovale v pliocenu in zgodnjem pleistocenu, holocenski erozijski jarki pa le v severnem in vzhodnem delu vrtače. Prerazporeditev smeri odtekanja deževnice je verjetno posledica tanjšanja puhlice v smeri sever-jug zaradi vlažnejšega holocenskega podnebja. Glede na prisotnost oksidiranih sedimentov, odsotnost šote in drugih jezerskih sedimentov ter majhno vsebnost vode $\mathrm{v}$ sedimentih nad matično kamnino, sklepamo, da je Meggyespuszta ena največjih aktivnih vrtač v Transdonavskem hribovju.
\end{abstract}

Ključne besede: paleovrtača, paleokras, Transdonavsko hribovje, Transdonavski tip krasa.

\footnotetext{
${ }^{1}$ University of Pannonia, Department of Limnology, H-8200, Veszprém, Egyetem utca 10, e-mail: atrajer@gmail.com.

${ }^{2}$ MTA-PE Limnoecology Research Group, H-8200, Veszprém, Egyetem utca 10.

${ }^{3}$ BudapestUniversity of Technology and Economics, Department of Construction Materials and Engineering Geology, H-1111, Budapest, Müegyetem rkp. 3. K 185.

${ }^{4}$ Corvinus University of Budapest, Faculty of Landscape Architecture, Department of Garden and Open Space Design, H-1118, Budapest, Villányi út 29-43.

${ }^{5}$ MTA Centre for Ecological Research, Institute of Ecology and Botany, H-2163 Vácrátót, Alkotmány utca 2-4.
}

Received/Prejeto: 17.04.2014 


\section{INTRODUCTION}

City of Veszprém is the seat of Veszprém County in North Transdanubia, Hungary. It was built on the Veszprém plateau, which is the main karst aquifer of the area and an important part of the water catchment of Lake Balaton, the largest shallow lake of Central Europe (Jordan et al. 2005). The land between cities Veszprém and Várpalota is a typical karstic landscape of the 200 million years old Transdanubian Range with karren fields, karstic erosion valleys and covered dolines. Exhumed paleokarst struc-

\section{GEOLOGICAL ENVIRONMENT AND CONSTRUCTION SETTINGS OF THE STUDIED AREA}

The Transdanubian Mid-mountains are part of the Bakony-Drauzug Unit which is a separate tectono-facial unit of the Alpine system (Kázmér 1984). It was made up of a lithosphere fragment which was broken off from the African Plate and reached its recent position by counterclockwise rotation process in $18-17$ and $16-14.5 \mathrm{Ma}$ in

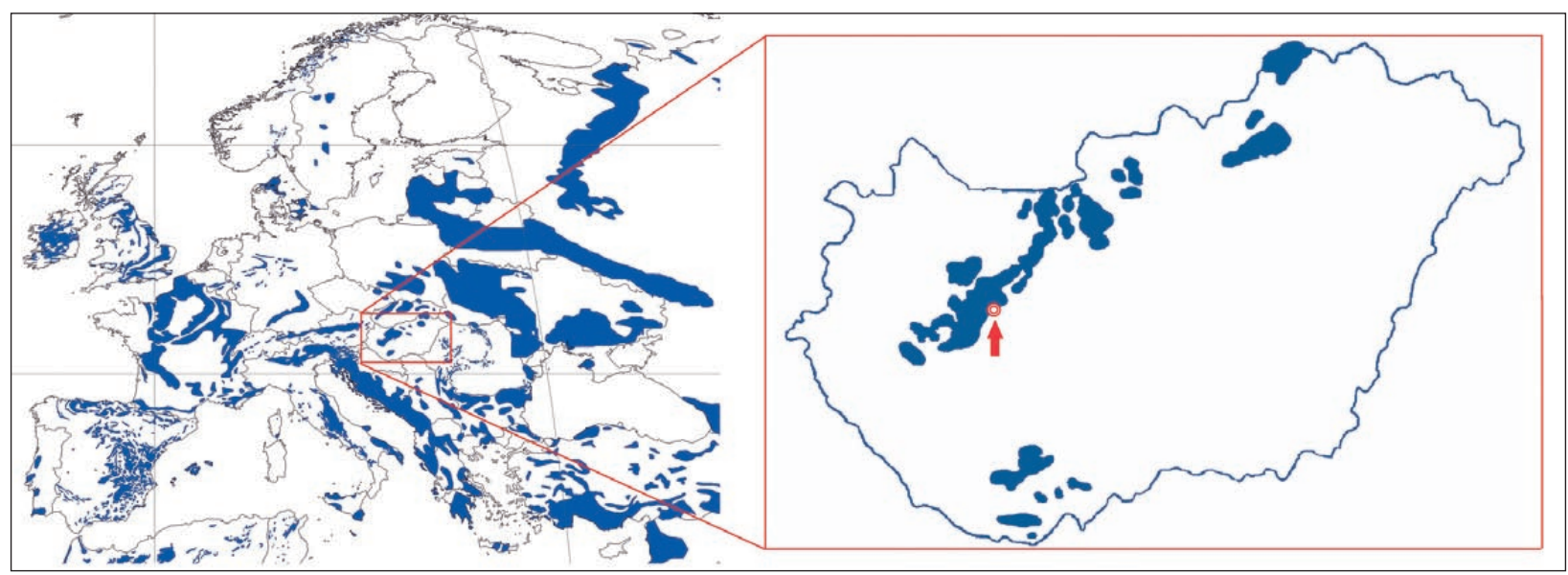

Fig. 1: The carbonate outcrop areas of Europe (blue spots) and the site of the study in Hungary projected to the Mesozoic (dominantly) carbonate formations (red arrow marks the site). The picture was based on the World Map of Carbonate Rock Outcrops v3.0 project of the University of Auckland (http://web.env.auckland.ac.nz/our_research/karst/) and the map of the geological structures of Hungary from the homepage of Eva Hartai (http://fold1.ftt.uni-miskolc.hu/ foldshe/mof0o.htm).

tures are frequent in the Transdanubian Range (Osborne 2002, Korpas et al. 1998, 1999). It is widely accepted that paleokarst is the target of the recent karstification, since paleokarst objects can be exhumed or reactivated in many times and this process can be more common than it is currently thought (Osborne 2002, Ford 1995). The Meggyespuszta paleodoline is located $1.6 \mathrm{~km}$ west of Szentkirályszabadja and $1.8 \mathrm{~km}$ south of Veszprém in the eastern part of the Balaton Highland in Transdanubia, in the Kasza-valley (Fig. 1). The Mesozoic dolomite karst of the Balaton Highland is a western part of the Transdanubian Mountain Range. Though the well-developed dolines are rare in the area due to the dominance of the porous Main Dolomite Formation, bare karren fields without sinkholes are the typical features of the landscape of the eastern part of Balaton Highland and the area near to Veszprém (Bárány and Kevei 2005). In the Bakony Mountains, karstic objects of the Tés Plateau form active karst area and there are also several buried paleokarstic objects (Móga and Németh 2005, Pokritem 2005). the Miocene Epoch according to paleomagnetic measurements (Tari 1991; Márton and Fodor 2003). The bulk of the Balaton Highlands is built up mainly of Middle and Late Triassic carbonates which were deposited on a shallow-marine carbonate platformin the western bay of the Neo-Tethys Ocean under tropical conditions (Pálfy 1991). Fragmentation and brecciation of the bedrock carbonate started in the MiddleCretaceous times due to the formation of Alpine-Pannonian structural bend (Fodor et al. 2005) resulting the fragmentation into blocks of the carbonate domain (Balla 1988). At least four or five major brittle deformation events affected the rigid carbonate block (Márton and Fodor 2003). This kind of karst area, which was strongly affected by tectonic movements, genetically belongs to the Transdanubian karst type of Hungary (Bárány and Kevei 2005). The Balaton Highlands were uplifted and suffered erosion during the Cretaceous and the Paleogene in several times due to the different phases of the Alpine orogeny (Budaiand Csillag1998). The dominant rocks of the Balaton Highlands are Middle Triassic limestones and dolomites, overlain with a rather 

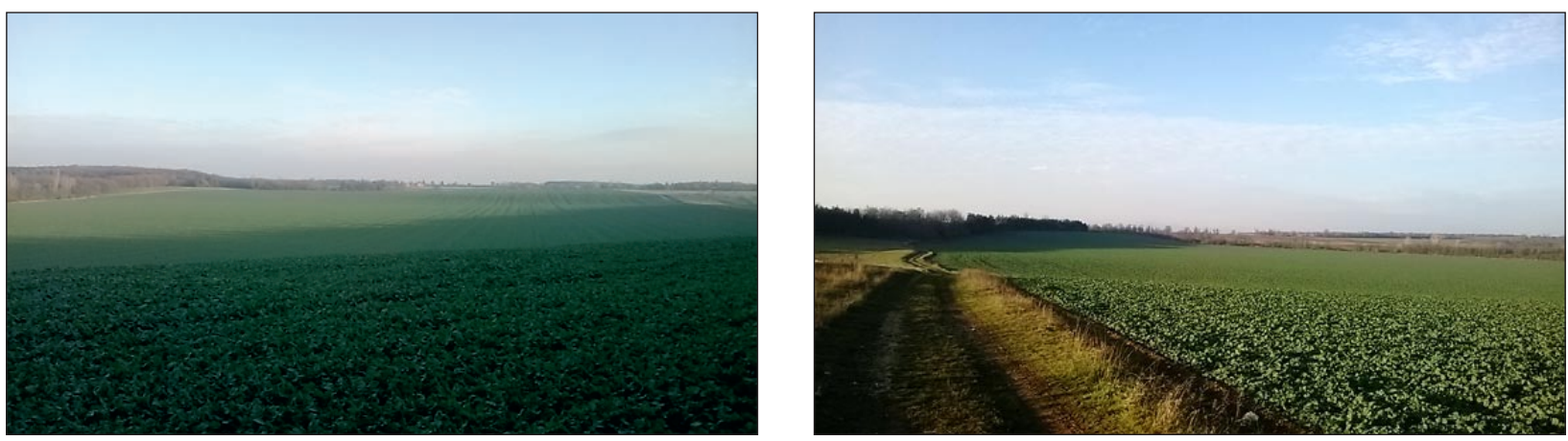

Fig. 2: Panorama from the northwestern and southwestern edge of the paleodoline

large apparent stratigraphic gap by Miocene sediments and volcanites representing the oldest known Cenozoic sediments of the area and relatively thin Pannonian Sandstone beds cover the thick, Mesozoic or Paleozoic karst water-bearing aquifer (Nemeth and Martin 1999). Quaternary deposits consist of alluvial sediments in valleys and the not too thick, partially eroded Pleistocene loess is characteristic of the Balaton Highland (Jordan et al. 2005).

\section{GEOMORPHOLOGY OF THE MEGGYESPUSZTA PALEODOLINE}

The coordinates of the center of Meggyespuszta paleodoline (Fig. 2) are N47 $03^{\prime} 40^{\prime \prime} \mathrm{E} 17^{\circ} 56^{\prime} 10^{\prime \prime}$. The diameter of the paleodoline is about $820 \mathrm{~m}$ north to south and $709 \mathrm{~m}$ east to west. The average diagonal diameter is about $798 \mathrm{~m}$. The relief is continuously decreasing from the wider relief to the centrum of the paleodoline. The mean height of the rim $(286.5 \mathrm{~m}+/--4.5,3.5 \mathrm{~m})$ measured from the height of the points of one radius distance is $-10.5 \mathrm{~m}$. The lowest point of the floor is $276 \mathrm{~m}$ above the Adriatic Sea level. The area of the paleodoline with the adjacent south erosional valley is $0.529 \mathrm{~km}^{2}$ and proluvial-deluvial sediments on the surface cover about $0.562 \mathrm{~km}^{2}$. The perimeter of the paleodoline with the south erosional karst valley is $3266 \mathrm{~m}$. The paleodoline has an irregular round shape which is partly opened to south (Fig. 3).

The Meggyespuszta paleodoline does not have permanent inflows or outflows and the nearest erosional valleys of other drainage basins are situated $1128 \mathrm{~m}$ and $973 \mathrm{~m}$ northwest and $786 \mathrm{~m}$ south. The distances of southeast part of the south erosional valley from the northeast points of the three adjacent valleys are only $586 \mathrm{~m}, 639 \mathrm{~m}$ and 646 meters. The length of the south erosional valley is about $500 \mathrm{~m}$, it is filled by young slope sediment as the centrum of the paleodoline. The soil cover of the south rim was formed in Middle Triassic limestone and dolomite bedrocks. The length of the visible major northern gully is $857 \mathrm{~m}$ and partly filled by proluvial-deluvial sediments. It was formed in Pleis-

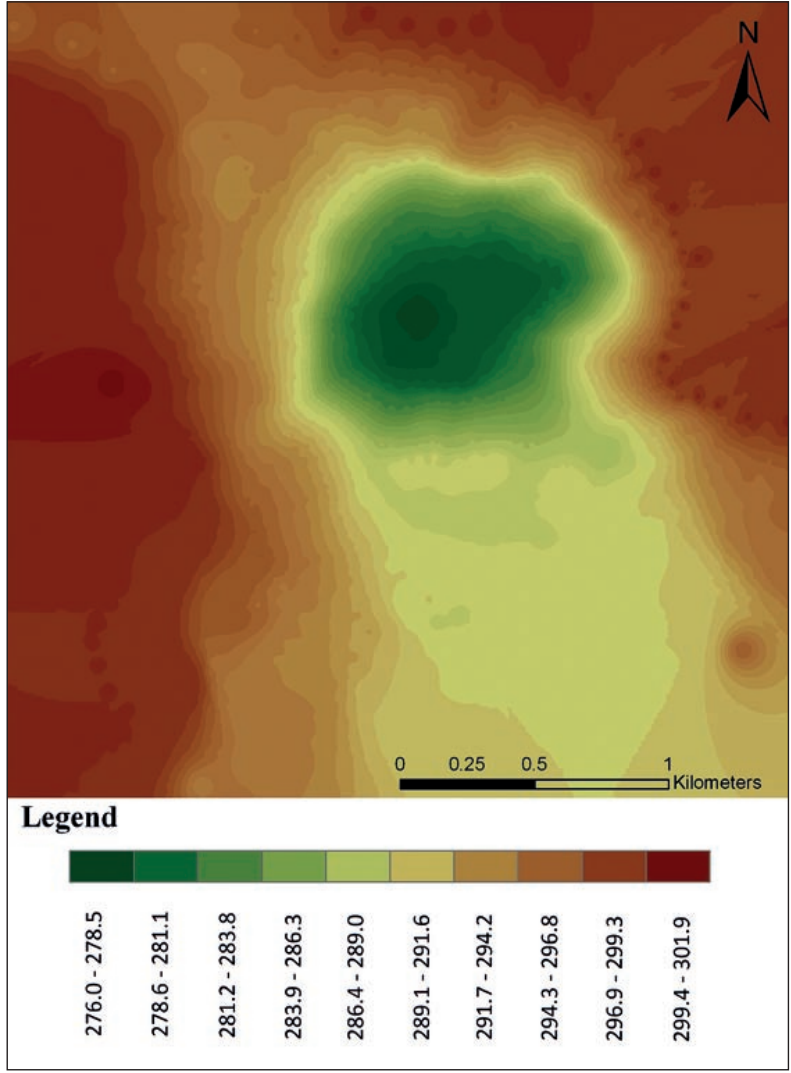

Fig. 3: The relief model of the paleodoline. The numbered colors indicate the altitude intervals above sea level in meter.

tocene loess according to the field survey. The major gully and the smaller branches in the loess incise in the northern north-eastern rim of the paleodoline. These young branching gullies carry rainwater and meltwater occasionally during greater rainfalls or after the melting of snow. In case of the major gully we found the sign of the recent alluvial transport after rainfall in the form of soil erosion furrows. In the mouth of the major gulley is about 2 to 3 meters deep and 3 to $4 \mathrm{~m}$ wide. The deposit of the valley is appear in the relief map as the withdrawing of the 280, 281 and $282 \mathrm{~m}$ contour lines to the cen- 


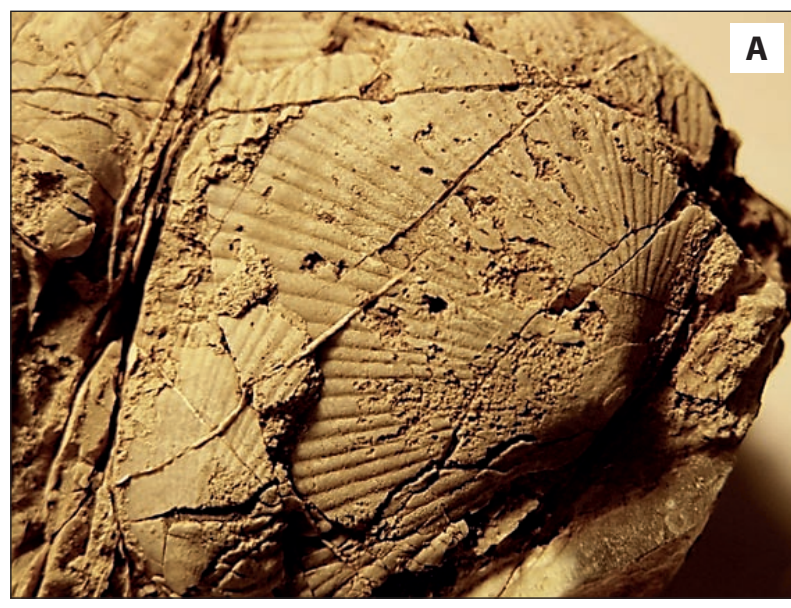

trum in the northeast part of the paleodoline. The major gully seems to be young and its slope is about continuous from the edge to the floor of the paleodoline. The forming of the minor gullies could be the consequence of agricultural caused soil erosion.

\section{THE TECTONIC POSITION OF THE MEGGYESPUSZTA PALEODOLINE AND THE SURROUNDING FORMATIONS}

Southeast from the paleodoline, the upper AnisianLadinian Buchenstein Limestone Formation tectonically has direct contact with the younger, Late Ladinian - Early Carnian Budaörs Dolomite Formation with nearly the same age, the Middle-to Late Anisian Felsöörs Formation, an another block of the Buchenstein-Felsöörs Formation, and presumably with the older, Middle- to Late Anisian Megyehegy Dolomite Formation. The Early to Middle Anisian Iszkahegy Limestone Formation forms the bedrock of the Megyehegy Dolomite Formation from south. Along the transform fault, about $162 \mathrm{~m}$ horizontal shift in northwest-southeast direction can be measured. The series of Iszkahegy Limestone Formation (Felsöörs and Buschenstein limestone Formation) and Budaörs Formation is also apparent at the southwest corner of the paleodoline in the same order. The geological overview of the paleodoline was based on the geological map of 1:1600000 spatial resolutions from the Geological Institute of Hungary (Geological Map of Hungary) and our field re-survey. We found Middle Triassic Daonella sp. (Fig. 4A) (Vászolyi Division) and cherty limestone (Nemesvámos Division, Fig. 4B) in the outcrop of the Buchenstein Limestone in the southeastern part of the paleodoline.

On the south side of the paleodoline we found karstified Budaörs Dolomite Formation rocks. Quaternary loess covers the surface on the northern, and deluvial silt and debris on the southeastern part of the paleodoline. Proluvial sediment fills the major gully of the

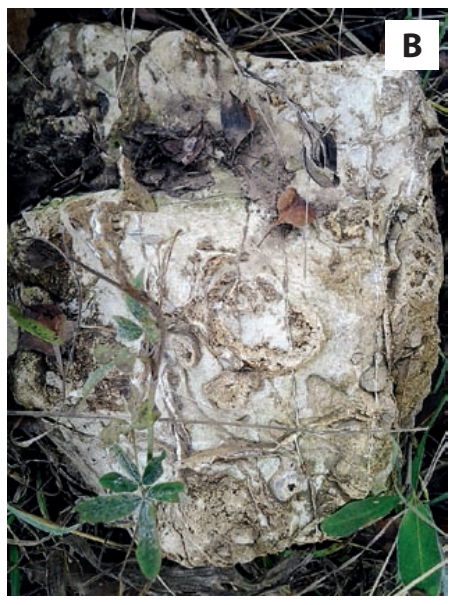

Fig. 4: A) Daonella sp. from the Middle Triassic Buchenstein Limestone Formation outcrop of the southeastern part of the paleodoline (the enlargement is 2,5:1); B) cherty Buchenstein Limestone Formation (Nemesvámos Division) in the southeast part of the paleodoline.

north-eastern edge and the paleodolineis filled by proluvial-deluvial sediment. Since the Buchenstein Limestone Formation is in a wedged position between the Budaörs Dolomite Formation from east and the merged Buchenstein-Felsőörs Limestone Formation from west, a perpendicular buried fault should be exist under the southern erosional karst valley (Fig. 5).

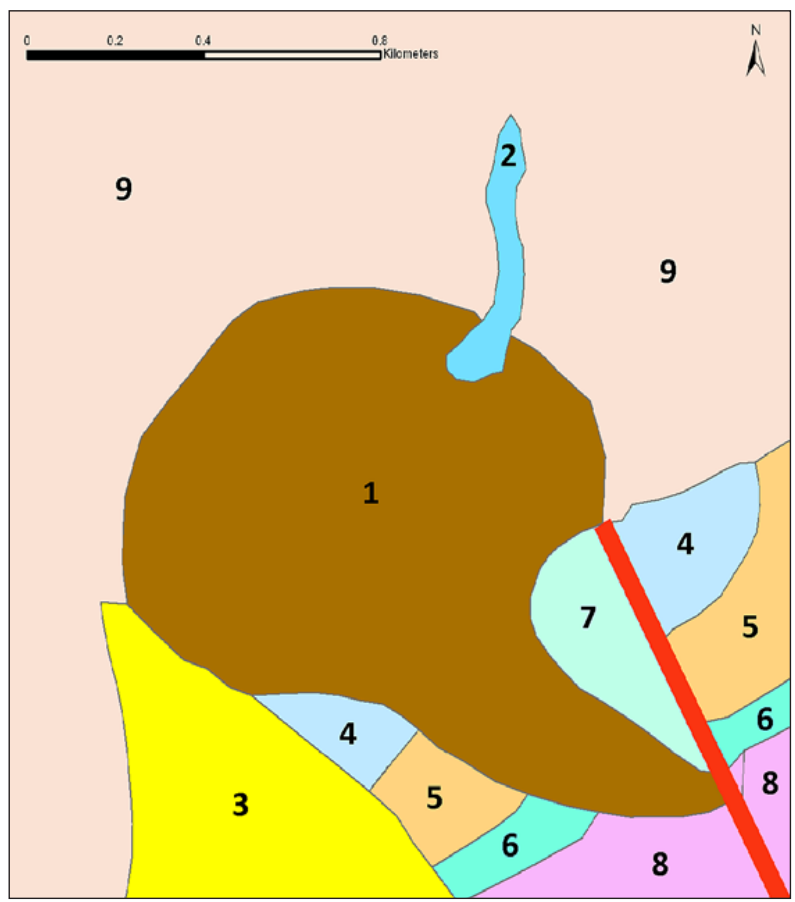

Fig. 5: The geological map of the environment of the Meggyespuszta paleodoline. 1: slope sediment, 2: proluvial-deluvial sediment, 3: deluvial silt and rock debris, 4: Budaörs Dolomite Formation, 5: the merged Felsöörs and Buchenstein Limestone Formation, 6: Megyehegy Dolomite Formation, 7: Buchenstein Limestone Formation, 8: Iszkahegy Limestone Formation, 9: loess, red line: fault (Source: The 1:100000 resolution Geological map of Hungary and our field surveys, Gyalog and Síkhegyi 2005). 


\section{MATERIALS AND METHODS}

\section{THE DATA OF THE BOREHOLE CORES}

The archive documentation of all the previously established boreholes within the study area and the description of the core samples were reviewed. We received the data of the borehole cores from the archives database of the Hungarian Mining and Geological Survey (Tab. 1; Szepesházyné Kurimay and Papp (1987), Nardai et al. (1987a, b). Fig. 6 shows the sites of the boreholes within the paleodoline and Tab. 1 provides the most important data of the boreholes.

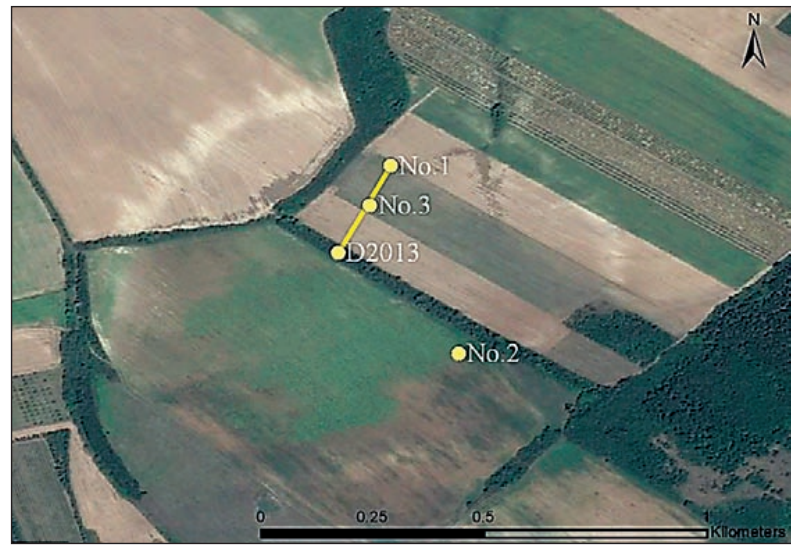

Fig. 6: The sites of the boreholes (yellow stars) on a satellite image. Orange line marks the cross section of the Fig. 13.
$4.8 \mathrm{~m}-29 \mathrm{~m}$, strata thickness: more than $24.2 \mathrm{~m}$ ). The firm rocks of the Budaörs Dolomite Formation can be found on the surface in the southwestern part and near to the eastern part of the paleodoline (Fig. 7A).

No.2. The following strata were described: 1. Holocene brown forest soil, formed on sandy loess (relative depth: $0.9 \mathrm{~m}$, strata thickness: $0.9 \mathrm{~m}$ ), 2. Unstratified loess. The upper $20 \mathrm{~cm}$ is slightly calcareous (relative depth: 0.9-2.1 m, strata thickness: $1.2 \mathrm{~m}$ ), 3. Limestone rock debris. In the uppermost parts the material is mixed with loess and potassium-rich trachytic tuff. 4. Middle Triassic cherty tuff in limestone matrix which contains bright green bentonite. Major tuff layers were found under 5.1-10.5, 11.7-11.8, 15.0, 15.9-16.6 $\mathrm{m}$ the surface. Below $16.7 \mathrm{~m}$ significant tuff layer was not observed. In the upper parts the limestone has tuberous appearance. The description refers to the tuffaceous strata of the Late Anisian and Early Ladinian Buchenstein Formation, the Vászoly Member (Budai and Dosztály 1990). The limestone component becomes more significant and compact in the lowermost part of the strata. The gap filling material is potassium trachit tuff and potassium bentonite. This potassium-rich illitic clay was formed from the alteration of volcanic ash syngenically in the Middle Triassic Buchenstein Limestone Formation (Budai and Csillag 2001; Fig. 7B).

Tab. 1: The most important details of the boreholes in the paleodoline. AT = Attila Trájer, TH = Tamás Hammer; SzKA = Ágnes Szepesházyné Kurimay, PP = Péter Papp, ZN = Zoltán Nardai, Dániel Bihari, ZsT = Zsuzsanna Tima

\begin{tabular}{l|l|l|l|l|l}
\hline Sample number & $\begin{array}{l}x, y \text { coordinates of the } \\
\text { borehole }\end{array}$ & Described by & $\begin{array}{l}\text { Elevation above sea } \\
\text { level }\end{array}$ & Date & $\begin{array}{l}\text { Max. depth } \\
\text { reached }\end{array}$ \\
\hline D2013 & $17^{\circ} 56^{\prime} 11.22^{\prime \prime}$ & AT, TH & $278.7 \mathrm{~m}$ & 2013.12 .13$. & $6.7 \mathrm{~m}$ \\
\hline No.1. & $17^{\circ} 56^{\prime} 15.20^{\prime \prime}$ & ZN; DB & $279.2 \mathrm{~m}$ & $1987.08 .10-15$. & $29.0 \mathrm{~m}$ \\
\hline No.2. & $17^{\circ} 56^{\prime} 18.93^{\prime \prime}$ & ZN; DB; ZsT & $278.7 \mathrm{~m}$ & $1987.08 .06-09$. & $20.2 \mathrm{~m}$ \\
\hline No.3. & $17^{\circ} 56^{\prime} 13.52^{\prime \prime}$ & PP; ÁKSz & $279.0 \mathrm{~m}$ & 1987.09 .29$. & $5.0 \mathrm{~m}$ \\
\hline
\end{tabular}

No.1. The following strata were described in the borehole material: 1. Holocene brown forest soil, formed on sandy loess (relative depth: $0-1.2 \mathrm{~m}$; strata thickness: $1.2 \mathrm{~m}$ ), 2. Pleistocene sandy loess without visible stratification, in the lowermost part of the section the greenish tinge disappears and little dolomite rock debris can be found. (Relative depth: 1.2 to $2.6 \mathrm{~m}$; strata thickness: $1.4 \mathrm{~m}), 3$. Dense, homogeneous reddish brown clay, occasionally with black limonite stains, bauxitic material and pisoids (relative depth: $2.6-4.8 \mathrm{~m}$, strata thickness: $2.2 \mathrm{~m}), 4$. Dolomite flour, the weathered material of the Early Ladinian - Early Carnian Budaörs Dolomite Formation. Budaörs Dolomite Formation: shallow-marine, reef and lagoon limestone or dolomite (relative depth:
No.3. In the paleodoline No.3. borehole found silt and sandy dolomite debris to $4.95 \mathrm{~m}$ depth. From 4.95 to $5 \mathrm{~m}$ dolomite was found.

\section{THE DRILLING OF A NEW BOREHOLE}

A new borehole was drilled about $86 \mathrm{~m}$ from the geometric center and $285 \mathrm{~m}$ from the nearest northern part of the rim (23.18\% of the radius from the center) with a Pioneer borer of $75 \mathrm{~mm} \times 1 \mathrm{~m}$ bit to make a $6 \mathrm{~m}$ deep borehole by dry drill technic. The new drill was named "D2013". The core samples were described by the authors. Borehole samples were weighed and dried at $105^{\circ} \mathrm{C}$ for 24 hours to constant weight. Water content of the samples was measured as weight loss of the material on drying. 


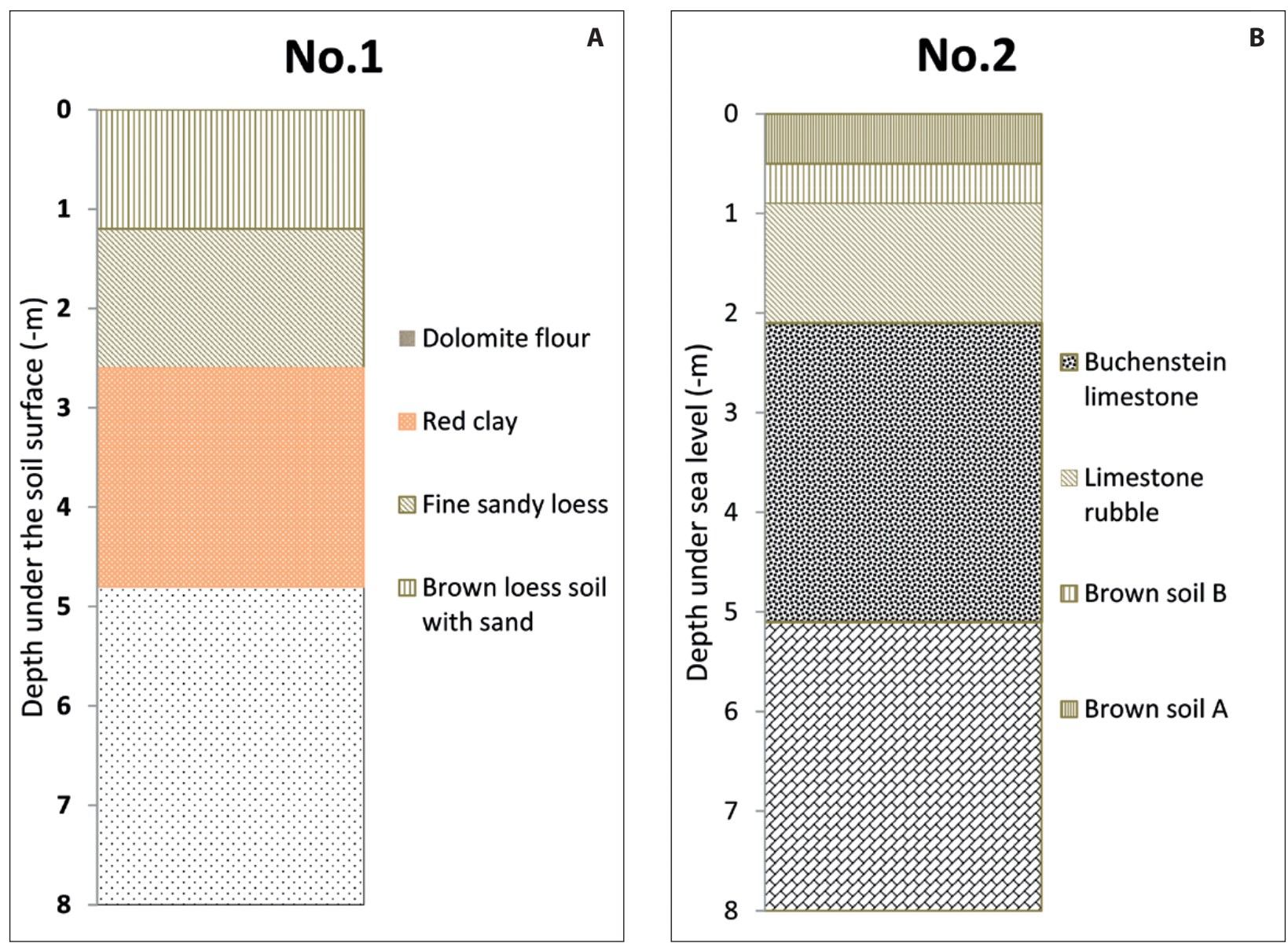

Fig. 7: The schematic lithological columns of the No.1 and No.2 boreholes.

Moisture content $(A \%)$ was expressed by the percentage of the sample's dry weight according to the Annual Book of American Society for Testing and Materials Standards. The total evaporable moisture content in Aggregate (C 566-13) can be calculated with the formula:

$$
A \%=\left[\frac{(M v e t-M d r y)}{M d r y}\right]
$$

Mwet $=$ the weight of the natural samples $M d r y=$ the weight of the dried samples

\section{GEOGRAPHICAL DATA AND THEIR PROCESSING}

Elevation data were based on the satellite images of Google Earth ${ }^{\mathrm{TM}} 2013$ application of the visible spectrum. Google Earth provides longitudinal, latitudinal and vertical coordinates. Due to the original resolution of the database the spatial resolution of our maps is one meter. We used the site appointing function of Google Earth imagery to mark the points with the equal elevations of the relief. Each marked points were named after its ver- tical coordinates. The designated spatial data were converted into keyhole markup language $(\mathrm{kml})$ file format type (altitude or gamma intensity data). After opening the $\mathrm{kml}$ data they were converted into shape file format in the ArcGIS 10.1 software. To create topographical images, we linked the points with equal vertical values. The different values were assigned into the referred points and were sorted into attribute table. We interpolated the values of the spatial data by the IDW interpolation function of the Spatial Analyst Tool in the ArcGIS. The interpolated vertical data were displayed as relief-like models. The sites of the boreholes were marked in georeferred orthophotos. Since the original spatial data of the earlier No.1, No.2 and No.3 boreholes were given by the Hungarian Military Stereographical System and the Budapest Stereographical System, at first, the points were converted according to the Unified Hungarian National Coordinate System and after the process these data were again converted by Psoft EOV-WGS'84 converter application according to WGS 84 to make this data suitable for the co-imagery of the other spatial data. To gain the northsouth cross section of the paleodoline, points through 
the center from north to south direction were chosen and a trend line was fitted on the points. To enhance the differences between the vegetation and the color of the soils and bedrock in case of Fig.9, we modified the true color of the original orthophoto by $800 \%$ color oversaturation by open access Adobe Photoshop Cs4. The border points of the catchment area were marked by a manual star-way scanning method. A point was considered as the local border of the catchment of the paleodoline if the elevation began to decline again frm the point moving ouward from the center.

\section{RESULTS}

\section{THE SOUTH PALEOKARSTIC EROSION VALLEY}

A greater and older erosional valley reaches the south part of the paleodoline. The valley was formed between the blocks of the Triassic dolomite and limestone formations, developing at the border of the covered and open karst surface. Dolomite rock vegetation was not found on the outcrops which may refer to a relatively young denudation of the surface. The longitudinal angle of the valley is about $1.1^{\circ}$, the cross-section angle of the slopes in the mouth of the valley is about $1.4-1.6^{\circ}$. The mouth of this valley is about one radius,

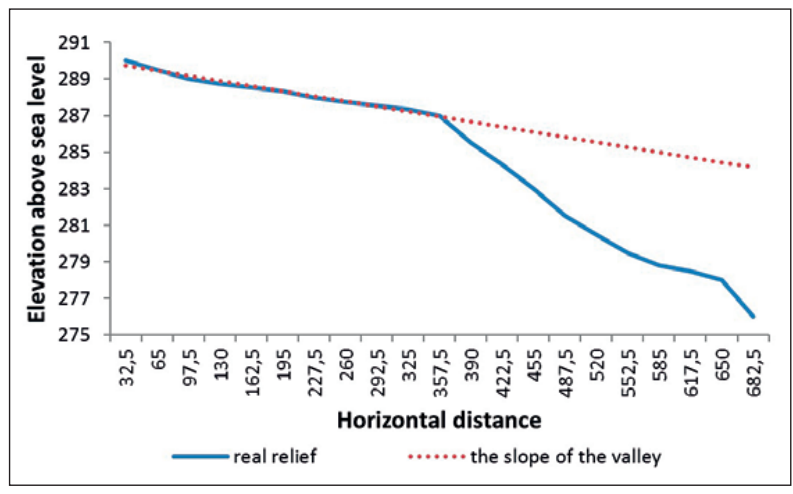

Fig. 8: The cross section of the south erosional valley from its origin to the central part of the object with the fitted trend line of the slope toward to the central of the paleodoline.
$500 \mathrm{~m}$ width and came from south-east and the valley has a U-shape in cross section. This valley having mean width of about $260 \mathrm{~m}$ does not show the signs of a more recent alluvial transport, and in contrast to the young northern valleys, it suddenly sink from rim of the paleodoline with a definite angle at $287 \mathrm{~m}$ above sea level which is also clearly visible in the field. The slope of the south valley from the $290 \mathrm{~m}$ to the $287 \mathrm{~m}$ above sea level point is very smooth, the highest deviations from the trend line points are $+0.268 \mathrm{~m}$ and $-0.048 \mathrm{~m}$. If the slope of the valley was the same to the deepest point of the paleodoline $(276 \mathrm{~m})$, the deepest point of the paleodoline would be at $284 \mathrm{~m}$ above sea level (Fig. 8).

The mouth of valley is sharply demarcated from the floor of the paleodoline in the visible satellite image and the oversaturated version (Fig. 9A and B).

In the entire length of the south rim of the paleodoline a sedimentary conglomerate were found from $30-40 \mathrm{~cm}$ under the surface, but the debris of the material is also clearly visible on the surface. The semi-consolidated material is cemented with calcic matrix and contains about $2-3 \mathrm{~cm}$ size angular or mainly poorly rounded clasts (Fig. 10A and B). The limestone, dolomite and cherty material of the clasts originates from the surrounding formations and contains well-rounded dolomite gravels (Fig. $11 \mathrm{~A}$ ), however, the cherty gravels which derive from the cherty material remained relatively angular.

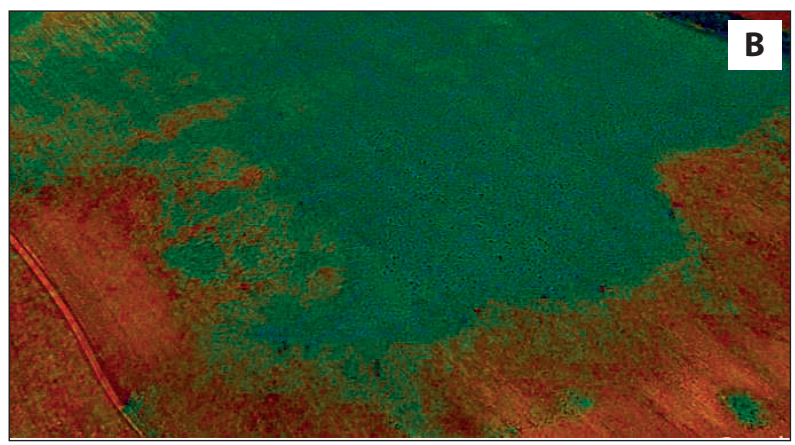

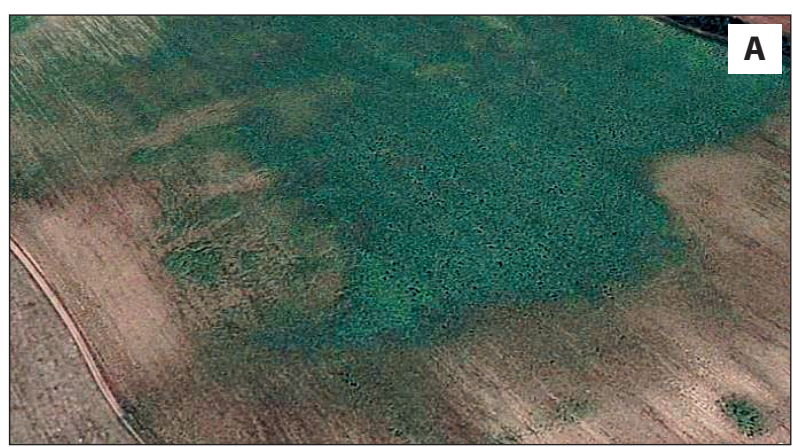

Fig. 9: A: the visible satellite image and $\mathbf{B}$ : the oversaturated false-colored image of the south part of the paleodoline. 

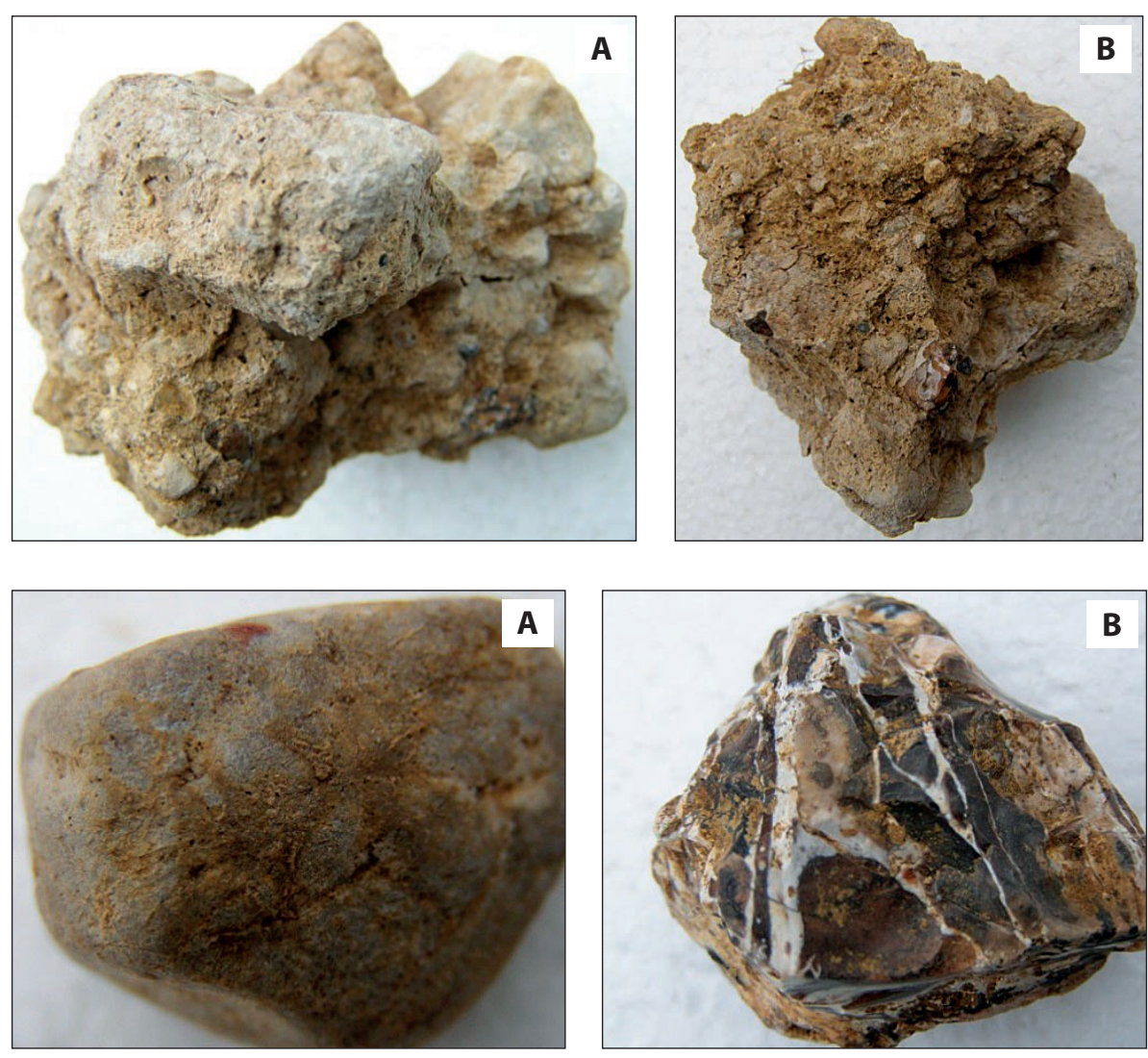

THE NEW BOREHOLE (D2013)

The following strata were described: 1. Brown forest soil, formed on sandy loess (relative depth: $0 \mathrm{~m}$ to $1 \mathrm{~m}$; layer thickness: $1 \mathrm{~m}$ ), 2. Sandy loess without visible stratification and paleosoil levels (relative depth: $1 \mathrm{~m}$ to $2.4 \mathrm{~m}$ ), 3 . Pale yellow, fairly homogenous, sandy dolomite powder, sandy dolomite debris without clear stratification; the upper part of the strata is mixed with loess and especially in the deeper parts of the strata contain few, $0.1-10 \mathrm{~mm}$ size angular dolomite rubbles ( 2.4 to $6.7 \mathrm{~m}$ ), 4. The bedrock is Budaörs Dolomite Formation from $6.7 \mathrm{~m}$ depth. The scratch color of the dolomite is white. It is notable that the dolomite powder was relatively dry and the bedrock was compact and firm. The borehole machine stopped when reached the firm dolomite bedrock. We did not observe any transitional strata between the bedrock and the dolomite powder. According to the nature of the deposit (lack of transitional material, only very few and small dolomite rubbles), the material was washed down from the close erosion surfaces in the past. The results of the No.3 and our borehole are similar, but the level of the bedrock is slightly different (Fig. 12).

\section{THE FLOOR OF THE PALEODOLINE}

The lowermost level of the loess strata of both the No.1 and No.2 boreholes are located at $276.6 \mathrm{~m}$ above the
Fig. 11: A well-rounded dolomite (A) gravel and an angular cherty gravel (B) from the south part of the paleodoline.

Fig. 10: The semi-consolidated conglomerate material from the south part of the paleodoline ( $A$ and $B$ ).

sea level (hence: a.s.1.) and for D2013 the lowermost level is above $276.3 \mathrm{~m}$ a.s.l. In contrast, the floor of the red clay strata of No.1aresituated at $274.4 \mathrm{~m}$, the floor of the No.2 core in $273.6 \mathrm{~m}$ a.s.l. with $420 \mathrm{~m}$ horizontal distance. The bedrock of the D2013 is above 272 $\mathrm{m}$ a.s.l., and that of No.3 is above $275.85 \mathrm{~m}$ a.s.l. It is important that while the D2013 found a firm dolomite material in $6.7 \mathrm{~m}$ depth the No.1 borehole found dolomite flour down to $29 \mathrm{~m}$. Moreover, while the No.1 borehole did not found firm dolomite bedrock, the close D2013 and No.3 reached the firm dolomite bedrock in 6.7 and $5.0 \mathrm{~m}$ from the recent surface. The red clay of strata of the No.1 core originally deposited on a dolomite flour of a karstic depression between the firm dolomite reefs of the Budaörs Dolomite Formation what was explored in the D2013 and No.3 boreholes (Fig. 13).

The water content of the borehole samples of D2013

The mean loss water weight of the samples as percent of the weight of the dry material was $10.89 \pm 1.58 \%$ in case of loess and $3.72 \pm 2.23 \%$ in case of silt (dolomite powder). Although the lowermost silt sample was the wettest, only in case of two samples reached the lost water weight the $3.8 \%$ of the dry weight value, and from $-250 \mathrm{~cm}$ to $640 \mathrm{~cm}$ it showed an increasing trend. It is 


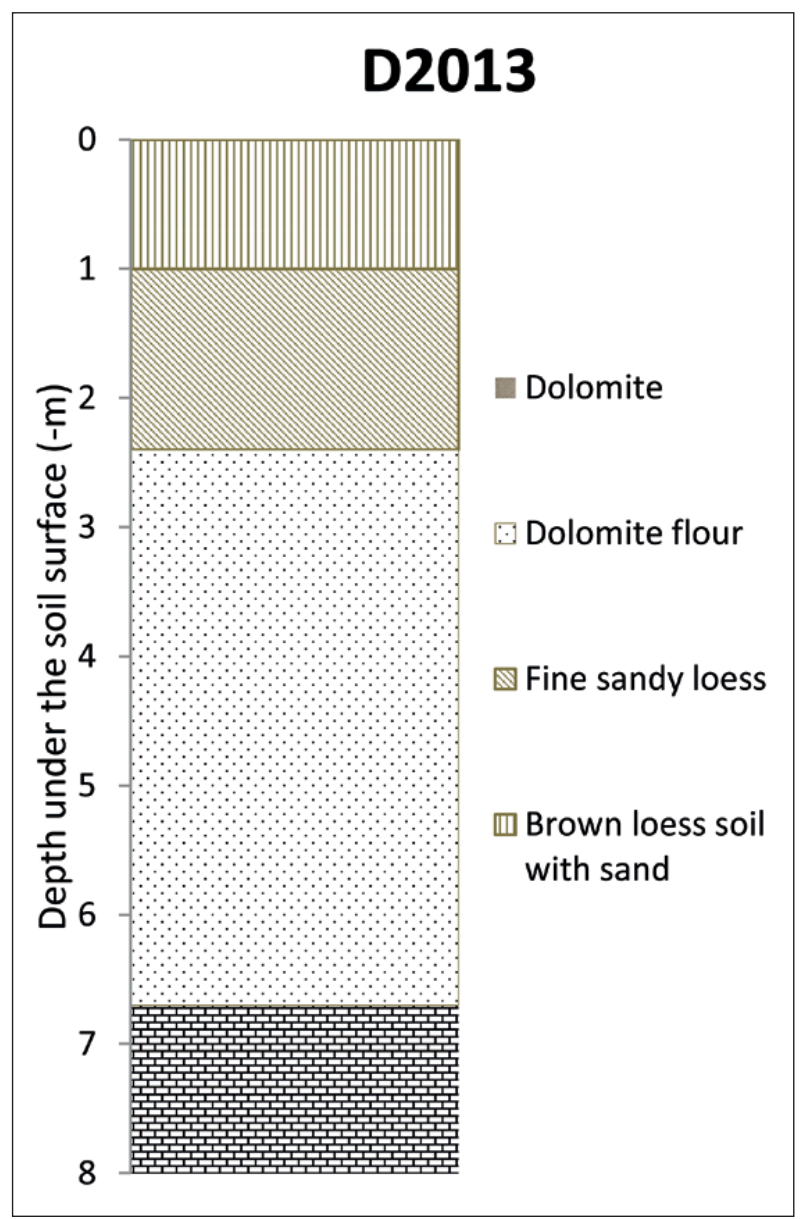

Fig. 12: The schematic lithological column of D2013 borehole.

notable that loess has better water absorption caption due to its higher clay content than the dolomite powder (Fig.14).

\section{THE CATCHMENT AREA OF THE PALEODOLINE}

The branching northern watershed "fingers" of the catchment border show the erosion of the loess cover and this

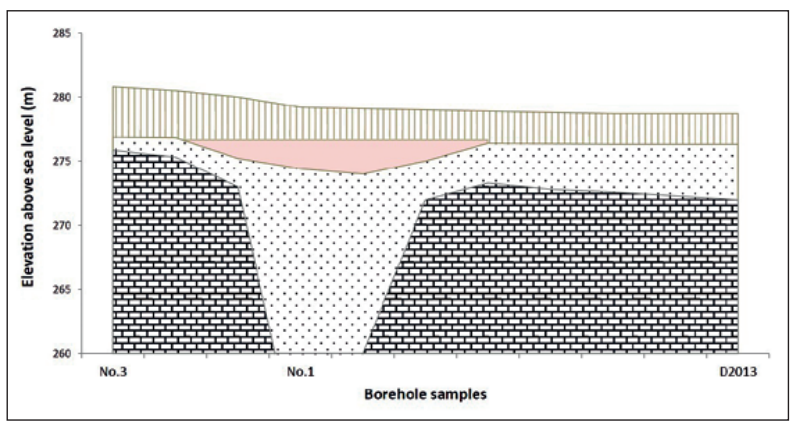

Fig. 13: The simplified cross-section model of the paleodoline between No. 3 and D2013 boreholes through the No.1 borehole with the red clay lens according to the results of the assessment of the core samples. The horizontal distance between the No.3 and D2013 is $22 \mathrm{~m}$.

area provides essentially the catchment of these branches. The northern border line of the drainage area also shows elongated, still partly ploughed erosional valleys in the loess cover indicating an active alluvial transport to the paleodoline (Fig. 15).

The area of the paleodoline itself is $0.397 \mathrm{~km}^{2}$, the area of the paleodoline with the southern erosion valley is $0.529 \mathrm{~km}^{2}$. The total area of the catchment area is $7.318 \mathrm{~km}^{2}$ and three major sub-valleys are noticeable (Fig. 16).

\section{RECONSTRUCTION OF THE NEOGENE AND QUATERNARY LANDSCAPE EVOLUTION}

We developed a possible reconstruction of the evolution of the paleodoline according to our stratigraphic results. The artistic reconstructions were based on the simplified cross-section between No.3 and D2013 boreholes through the No.1 borehole which was duplicated (Fig. 13). We divided the development of the paleodoline into three main stages, the Paleogene-Early/Middle Neogene, the Late Neogene-Early Quaternary and the Later Quaternary phases. The modeled vegetation was based on three typical fossil flora of Hungary from the adequate

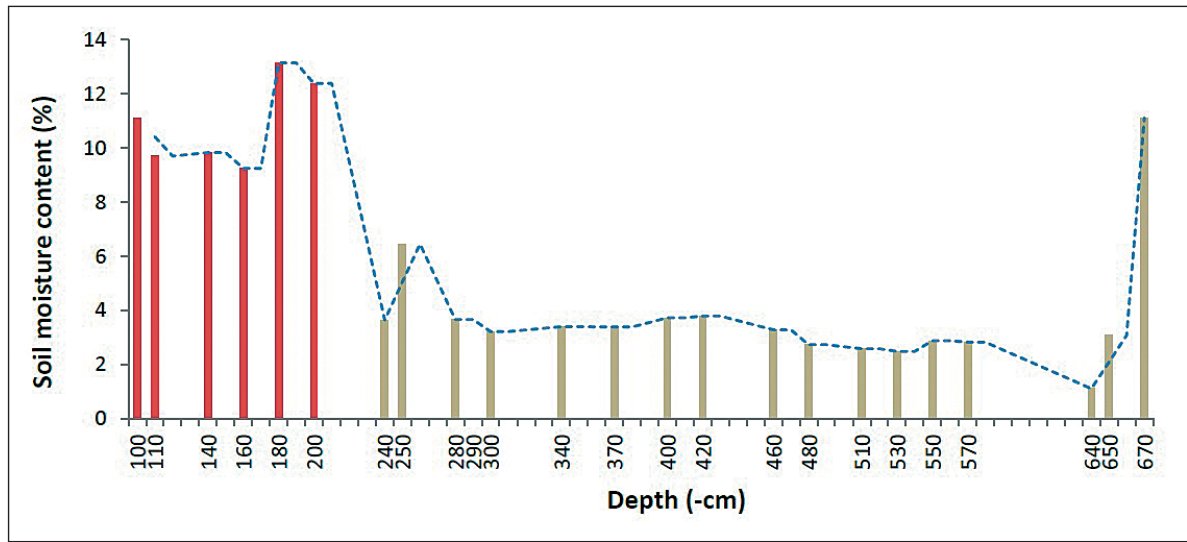

Fig. 14: The water content of the samples as \% of the weight of the dry material with moving average. Red column: loess samples, brown column: dolomite flour samples, dashed blue line: the moving average. 


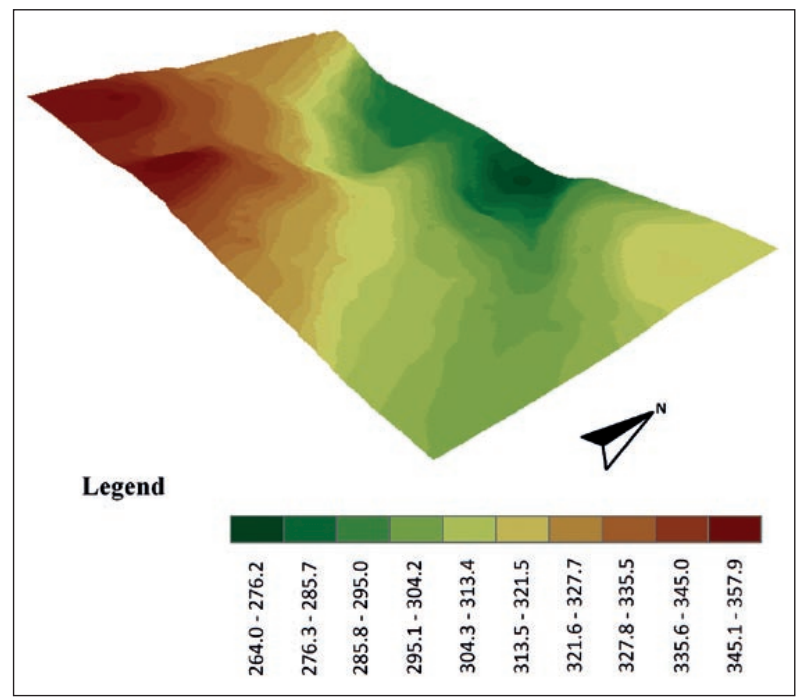

Fig. 15: Erosion valleys on loess in the northern neighborhood of the paleodoline south to Veszprém. The numbered colors indicate the altitude intervals above sea level in meter.

periods. The discussion of the reconstruction is readable in the next Chapter.

Stage 1. Vast Paleogene- Early-Middle Neogene karstification formed the uncovered carbonate surface after the denudation of the Eocene cover sediments under a warm and mostly wet or sometimes semidry subtropical/warm temperate climate creating relatively large dolines and karst valleys. The artistic reconstruction of the vegetation was based of the wet subtropical Early-Middle Miocene paleoflora of Ipolytarnóc (from Northern Hungary) including Daphnoglene bilinicaUnger, Engelhardia orsbergensis Wess and Web, Calamus noszkyJablonszky, Cyclocarya cyclocarpaSchlecht, Platanus neptuniEttingshausen and Sabal majorUnger palms ac-

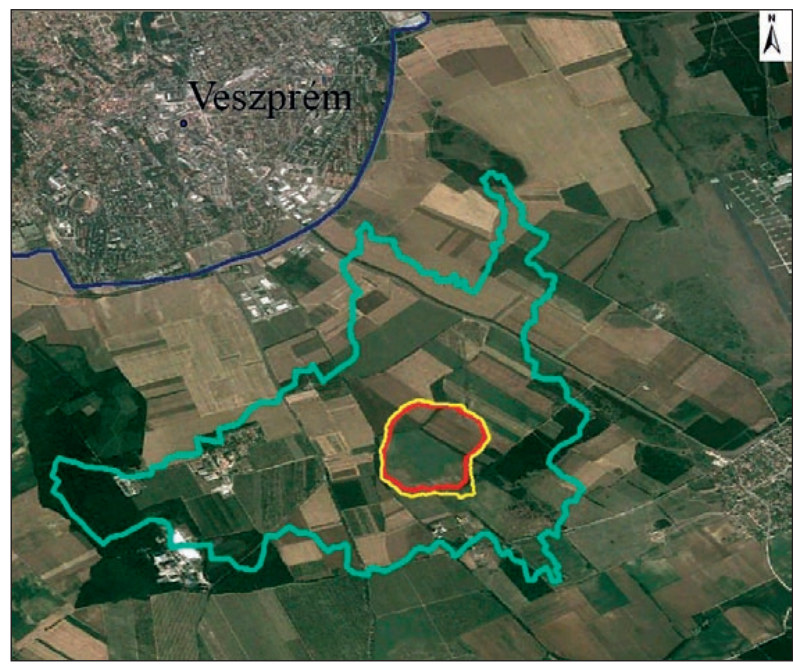

Fig. 16: The plan view of the northwest rim of the paleodoline and the catchment basin of the paleodoline. Blue line: town of Veszprém. Water catchment border: greenline. The contour lines show the rim of the paleodoline (red line marks the points of $282 \mathrm{~m}$, the yellow linethe points of $286 \mathrm{~m}$ a.s.l.).

cording to Hably (1986) and Rásky (1959). The green line refers to the presence of pteridophytes in the herb level e.g. Lobaria jablonszkyRásky andDryopteris kümmerleiJablonszky according to Erdei et al. (2011) (Fig. 17).

Stage 2. In the hollows of the relief, laterite-like soils were deposited in the second part of the Neogene (Fig. 18). The original clayey and bauxitic laterite soil cover was eroded from the relief and clayey material was preserved only in small lenses in the deepest depressions of the paleodoline. The relief might have suffered similar great erosion as were observed e.g. in the Dinaric Karst of Slovenia where it was found that if a doline began to develop at the start of Pleistocene, the

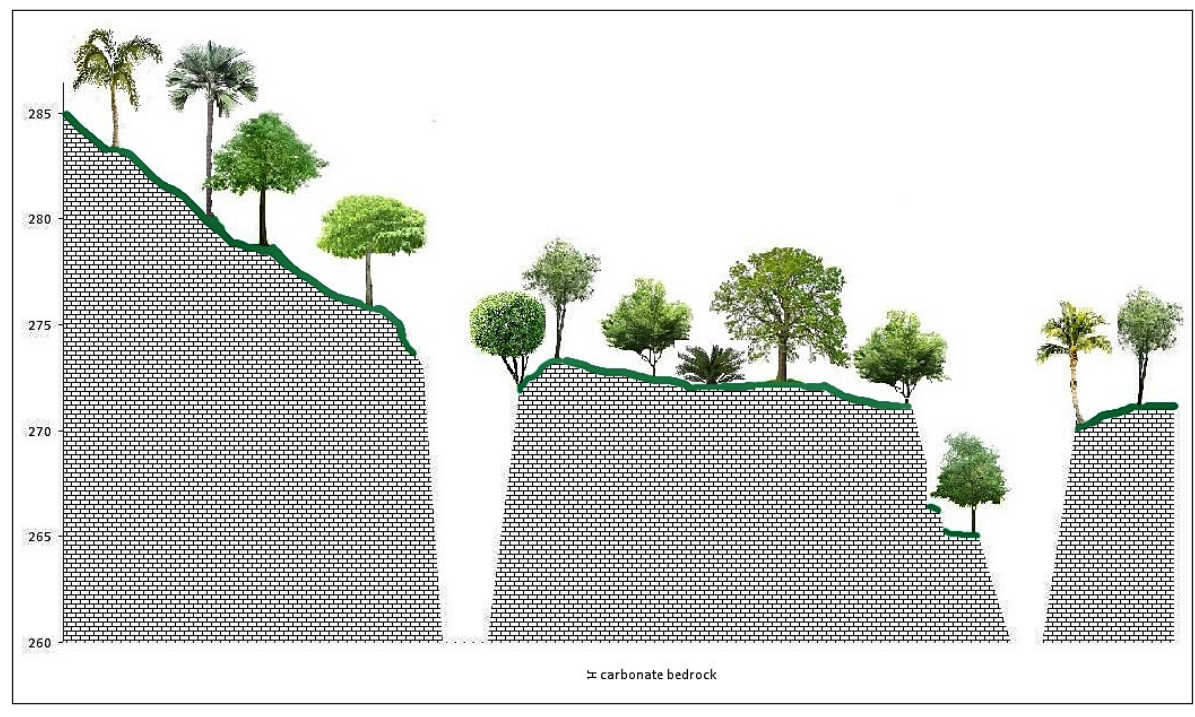

Fig. 17: The artistic reconstruction of the possibly partly $\mathrm{Pa}$ leogene, but rather most part Early-Middle Neogene stage of the development of the Meggyespuszta paleodoline according to the stratigraphic results. For details see the text. 


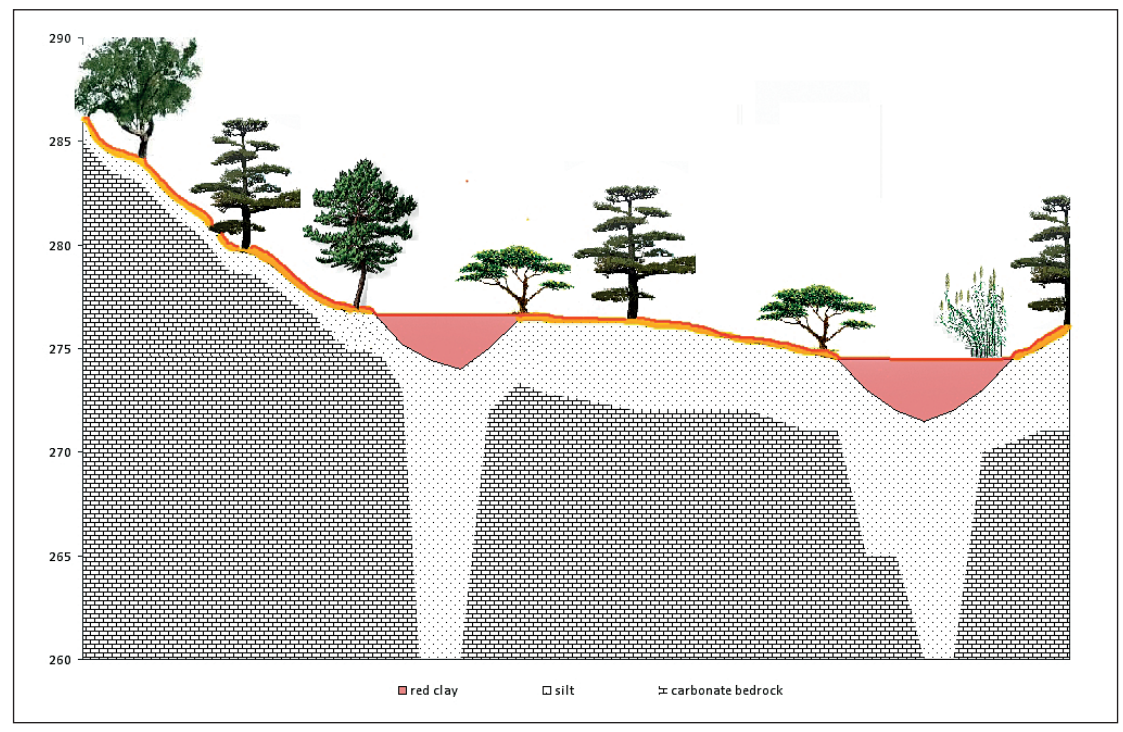

Fig. 18: Theartistic reconstructed Late Miocene, Early Pliocene stage of the development of the Meggyespuszta paleodoline stratigraphic results. For details see the text.

surface of karst relief lowered much more than the deep of the recent dolines (Gams 2000). It is accordance with the observed thick layers of silt and dolomite debris of the surrounding area The artistic reconstruction of the vegetation was based on the Late Miocene fossilized paleoflora of the Káli-basin (it is the small region of the Balaton Upland) with the found Rhamnus alaternus L., Pinus halepensis Miller (Fözy et al. 2014) which flourished under a Mediterranean, warm temperate (Mediterranean) climate.

Stage 3. In the milder and wetter interglacial episodes the climate was similar or even warmer than during the second part of the Holocene and karstification continued under the surface due to the porous loess and dolomite or limestone debris. The broad and well-developed catchment area shows that the erosion carried loess into the paleodoline before the Holocene from North. It is plausible that periglacial slope movements and periodic cryoturbation affected the southern slope of the paleodoline. Due to strong prevailing northern winds and the topography of the site, thicker loess strata cannot be accumulated in the karst plateau. These circumstances reversed the typical direction of the rainwater course from the South to North course of the Pliocene into the North to South course of the Holocene. The artistic reconstruction of the vegetation was based on the pollen analysis of the boreholes from the Little-Balaton area (Transdanubia) of the Early-Middle Holocene sediment zone of 10150-6700 BP when Pinus spp. dominated the vegetation (30-40\% of the pollen flora), but Betula spp. also contributed significantly $(15 \%)$ to the pollen flora according to Medzihradszky (2005); (Fig. 19).

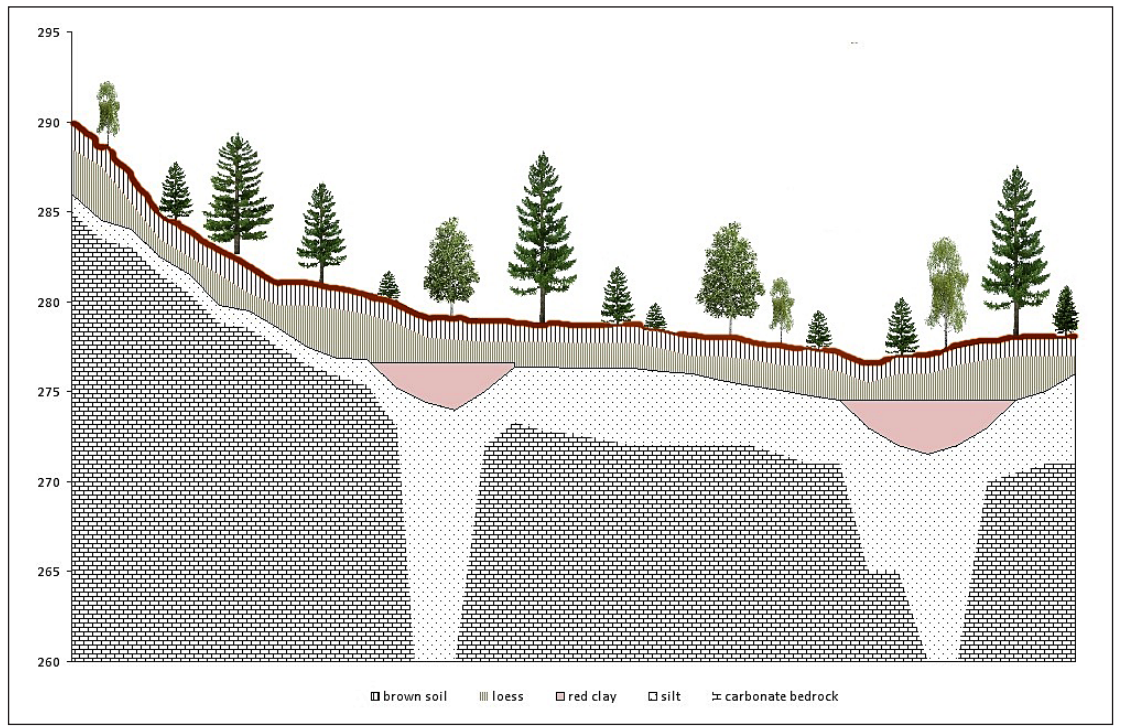

Fig. 19: The artistic reconstruction of the Quaternary development stage of the Meggyespuszta paleodoline based on the stratigraphic results. For details see the text. 


\section{DISCUSSION}

Although absolute age determination methods were not used, the stratigraphy of the sediments and the fossil karst features provide opportunity to determine the approximate age of the paleodoline. The red clay strata of No.1 can be the oldest determinable deposit in the paleodoline. Red clay forms the bedrock of the Pleistocene loessofNo.1 site. Two typical red clay formations are known from the second part of the Neogene of Transdanubia: the Miocene Vöröstó Formation and the Pliocene-Early Pleistocene age Red Clay Formation. Both formations are terrestrial, redeposited weathering materials which were formed under oxidative conditions. Bauxitic, red or variegated clay occurrences are well known from the karst covering deposits of the Transdanubian Range (Bárdossy\&Mindszenty 2013). The Vöröstó Formation is dominantly a reworked material. It has partly bauxitic origin and contains bauxitic clay loam, bauxite, laterite, sometimes bauxite gravels with high iron content. It was deposited in terrestrial environment due to the re-deposition of the earlier, uncovered bauxite formations when the protective cover of the Eocene limestones already had eroded. In most part of its occurrence it directly covers the karstified Triassic carbonate rocks. The age of this Formation can be Middle or Late Miocene or even to Upper Miocene. The red clay is a typical Pliocene - Early Pleistocene terrestrial deposit. It has alluvial-deluvial origin. Pliocene-Early Pleistocene red clays form the bedrock materials of loess formations in the Northern Hemisphere. The bedrock (the red clay sediments) of the oldest loess layers is the Dunavári Formation deposited in 3.2-2.0 Ma (Varga 1997). After the filling of the Pannon lake and the Messinian salt crisis (Messinian: 5.332-7.246 Ma), the climate became dry in the Carpathian Basin. The eolic sedimentation was dominant and real deserts or semi-deserts existed (Varga 1997). The typical red clays began to deposit about 3.6 million years ago in the boundary of the Zanclai (5.332-3.6 Ma) and the Piacenzai (3.6-2.588 Ma) periods when the climate became wetter. The annual mean temperature was about $3-5^{\circ} \mathrm{C}$ warmer than in the present times with $1200-1800 \mathrm{~mm}$ rainfall per year (Van Dam 2006). These red clays originally covered the relief as paleosoils (Kovács 2003). The caps of the red clays are loess and settled red paleosoils (Jámbor 1980; Halmai et al. 1982; Kovács et al. 2011; Kovács 2003).After the formation of red clays, the climate became drier and cooler in the border of the Pliocene-Pleistoce periods and grass vegetation or semi deserts replaced the earlier forests (Varga 1997). Since the boundary of the red clay and the loess formation is horizontal, it is plausible, that the tectonic movements have not affected the slope of the surface during the Quaternary. Hiatus between the Pliocene/Early Pleistocene and Middle- and Late Pleistocene formations is also unlikely to be due to the intact horizontal position of the uppermost layer of the red clay strata according to the lack of the erosion sediments and the topographical position. Theoretically, the Pleistocene covering with loess, the cold and the decreased precipitation decreased the level of karstification, but in temperate areas the cooler climate of the Pleistocene were associated with increased soil moisture due to the lower evapotranspiration with more intensive stone fracturing which might provide better conditions for doline development than the milder warmer periods of the Neogene or the Holocene (Gams 2000, 1993). The found, relatively dry material of the samples of the D2013 confirms the hypothesis, that the paleodoline is still active even though this sample shows conditions of a single moment. Today the valley is suitable for agriculture and the bottom of the valley recently is a cabbage and colza ground when the annual average precipitation is about 600 to $650 \mathrm{~mm}$. Overall, based on the sediments of the object, the doline was never covered with water for longer periods. The recent relative dryness of the sink can only be explained by thefact that the floor of the paleodoline has an active drainage. According to Jakucs (1971), most of the karst features in Hungary are residual karsts and the Meggyespuszta paleodoline can be one of the largest recently active examples of them. The paleodoline as a "time capsule" preserved the major environmental changes of the past in the area of Veszprém.

\section{ACKNOWLEDGEMENT}

The authors would like to say many thanks to Éva Zsadányi (Hungarian Geological Survey Office) who provided the historical data available about the previous boreholes, István László (Department of Geodesy, Hungarian Geological and Geophysical Institute) for his assistance in the conversation of the coordinate data, Mi- hály Pósfai, Andrea Mindszenty and Judit Szőnyi Mádlné and the reviewers for their revision of the manuscript.

The research was supported by the project TÁMOP-4.2.1/B-09/1/KMR-2010-0005 and TÁMOP (4.2.2. A-11/1/KONV-2012-0064, 1.1). 


\section{REFERENCES}

Balla, Z., 1988: Clockwise paleomagnetic rotations in the Alps in the light of the structural pattern of the Transdanubian Range (Hungary). Tectonophysics, 145(3), 277-292. http://dx.doi.org/10.1016/00401951(88)90200-4

Bárány-Kevei, I., 2005: Genetic types, human impact and protection of Hungarian karsts.-Acta Climatol Chorol Univ Szegediensis, 38-39, 17-23.

Bárdossy, Gy. \& A. Mindszenty, 2013: Az Iharkúti bauxite-előfordulás.-Geological and geophysical Institute of Hungary.133p.

Budai, T. \& G. Csillag, 1998: A Balaton-felvidék középső részénekf öldtana [Geology of the central part of the Balaton Highland (Transdanubian Range, Hungary)]. - A Bakony természettudományi kutatásának eredményei 22, 118 p.

Budai, T. \& G. Csillag, 2001: A Balaton-felvidék földtani térképezése (1982-1999), avagy: kalapáccsal Lóczy Lajos nyomában, Földtani Közlöny, 1-2, 285-289.

Budai, T. \& L. Dosztály, 1990: A Balaton-felvidéki ladini képződmények rétegtani problémái. The annual report of Geological Institute of Hungary about 1988 (A Földtani Intézet Évi Jelentése 1988-ról), 1, 61-79.

Erdei, B., Hably, L., Selmeczi, I. \& L., Kordos, 2011: Palaeogene and neogene localities in the North Hungarian mountain range. Studia Bot. Hung. 42, 153183.

Fodor, L., Csillag, G., Németh, K., Budai, T., Cserny, T., Martin, U., Brezsnyánszky K \& J. Dewey, 2005: Tectonic development, morphotectonics and volcanism of the Transdanubian Range: a field guide. Occasional Papers of the Geological Institute of Hungary, 204, 59-86.

Ford, D.C., 1995: Paleokarst as a target for modern karstification.- Carbonates and Evaporites, 10 (2), 138-147. http://dx.doi.org/10.1007/BF03175399

Fözy, I., Szente, I. \& G. Dyke, 2014: Fossils of the Carpathian Region, Indiana University Press, 508 p.

Gams, I., 1993: Origin of the term "karst" and the transformation of the classical karst (kras). Environmental Geology, 21(3), 110-114. http://dx.doi. org/10.1007/BF00775293

Gams, I., 2000: Dolie morphogenetic processes from global and local viewpoints.-Geomorfogenetski procesivrtač z globalnega in local negavidika. Acta Carsologica, 29(2), 123-138

Gyalog, L. \& F. Síkhegyi (eds.) 2005: Geological map of Hungary.The 1:100000 Geological map of Hungary (http://loczy.mfgi.hu/fdt100/) Last accessed: 2014.03.30.
Hably, L., 1986: Analysis of leaf size of the Ipolytarnóc flora from a climatological point of view. Stud. Bot. Hung, 19, 23-52.

Halmai, J., Jámbor, Á., Ravasz-Baranyai, L. \& I. Vető 1982:A Tengelic-2. sz. fúrásföldtani eredményei. A Magyar Állami Földtani Intézet Évkönyve, 65(1), $235 \mathrm{p}$.

Jakucs, L., 1971: A karsztok morfogenetikája.-AkadémiaiKiadó, p. 310, Budapest.

Jámbor, Á., 1980: A pannoniai képződmények rétegtanának alapvonatkozása. Általános Földtani Szemle, 14. pp. 113-124.

Jordan, G., Rompaey, A., Szilassi, V., Csillag, P., Mannaerts, G. \& C.T. Woldai, 2005: Historical land use changes and their impact on sediment fluxes in the Balaton basin (Hungary). Agriculture, ecosystems \& environment, 108(2), 119-133. http://dx.doi. org/10.1016/j.agee.2005.01.013

Kázmér, M., 1984: A Bakony horizontális elmozdulása a paleogénben. Continental escape of the BakonyDrauzug Unit in the Paleogene.- Általános Földtani Szemle-General Geological Review, 20, 53-101.

Kovács, J., Varga, Gy. \& J. Dezső, 2008: Comparative study on the Late Cenozoic red clay deposits from China and Central Europe (Hungary). Geological Quarterly 52. (4) pp. 369-382.

Kovács, J., Fábián, Sz.Á.,Varga, G., Újvári, G., Varga, Gy. \& J. Dezső, 2011: Plio-Pleistocene red clay deposits in the Pannonian Basin: A review. Quaternary International 240(1-2), 35-43.

Kovács, J., 2003:Vörösagyagok geomorfológiai helyzete és kora a Kárpát-medencében. http://old.foldrajz. ttk.pte.hu/tgt/web_kozlemenyek/kozl24/pte_termeszetfoldrajzi_kozlemenyek24.pdf). Last accessed in 2014.03.29.

Korpas L., Lantos, M. \& A. Nagymarosy, 1999: Timing and genesis of early marine caymanites in the hydrothermal paleokarst system of Buda Hills, Hungary.- Sedimentary Geology, 123, 9-29. http:// dx.doi.org/10.1016/S0037-0738(98)00090-6

Korpas, L., 1998: Paleokarst studies in Hungary. Occasional Papers of the Geological Institute of Hungary, 195, 1-139.

Márton, E. \& L. Fodor, 2003: Tertiary paleomagnetic results and structural analysis from the Transdanubian Range (Hungary): rotational disintegration of the Alcapa unit.-Tectonophysics, 363(3), 201-224. http://dx.doi.org/10.1016/S0040-1951(02)00672-8 
Medzihradszky, Z., 2005: Holocene vegetation history and human activity in the Kis-Balaton area- Western Hungary. Studia Botanica Hungarica, 36, 77100.

Móga, J. \& R. Németh, 2005: The morphological research of the Basalt and Loess covered plateaus in the Bakony Mts. (Transdanubian Middle Mts.-Hungary). Acta Carsologica, 34(2), 397-414.

Nardai, Z., Bihari, D. \& Zs. Tima, 1987A: Földtani napló a Szit-1. számú fúrásról. Nehézipari Minisztérium, OFKFV, Duántúli Üzemvezetőség, Várpalota.

Nardai, Z., Bihari, D. \& Zs. Tima, 1987B: Földtani napló a Szit-2. számú fúrásról. Nehézipari Minisztérium, OFKFV, Duántúli Üzemvezetőség, Várpalota.

Nemeth, K. \& U. Martin, 1999: Late Miocene paleogeomorphology of the Bakony-Balaton Highland Volcanic Field (Hungary) using physical volcanology data. Z Geomorph N. F. (Berlin, Stuttgard), 43(4),417-438.

Osborne, R.A.L., 2002: Paleokarst: cessation and rebirth. Evolution of karst: from prekarst to cessation. Postojna-Ljubljana, Zalozba ZRC, 43-60.

Pálfy, J., 1991: Paleoecological significance of Anisian (Middle Triassic) brachiopod assemblages from the Balaton Highland (Hungary). Mackinnon, D.I., Lee, D.E. \& J.D. Campbell (eds): Brachiopods through Time. Balkeema, Rotterdam, 241-246.
Rásky, K., 1959: The fossil flora of Ipolytarnoc (preliminary report). Journal of Paleontology, 33(3), 453461.

Szepesházyné Kurimay, Á. \& P. Papp, 1987: Földtaninapló a Szit-2.számúfúrásról. Nehézipari Minisztérium, OFKFV, Duántúli Üzemvezetőség, Várpalota.

Tari, G., 1991: Multiple Miocene block rotation in the Bakony Mountains, Transdanubian Central Range, Hungary. Tectonophysics, 199(1), 93-108. http:// dx.doi.org/10.1016/0040-1951(91)90120-H

Van Dam, J.A., 2006: Geographic and temporal patterns in the late Neogene (12-3 Ma) aridification in Europe: the use of small mammals as paleoprecipitation proxies. Palaeogeography, Palaeoclimatology, Palaeoecology 238(1-4), 190-218. http://dx.doi. org/10.1016/j.palaeo.2006.03.025

Varga, G., 1997: Bérbaltavárium (félsivatagi-sivatagiklíma) geomorfológiai és üledékföldtani bizonyítékai a Kárpát-medencebelsejében. Manuscript, Pécs, Hungary. http://foldrajz.ttk.pte.hu/files/doktoriskola/dokumentumok/VargaGy_disszertacio_NV.pdf. Last accessed in 2014.03.29. 